\title{
Pengaruh Model Pembelajaran Value Clrification Technique Bermuatan Nilai Karakter Terhadap Kompetensi Pengetahuan PPKn
}

\author{
Ni Putu Selly Lindayani ${ }^{1}$, Made Putra ${ }^{2}$, I. B. Surya Manuaba ${ }^{3}$ \\ ${ }^{123} J u r u s a n$ Pendidikan Dasar, Universitas Pendidikan Ganesha, Singaraja, Indonesia \\ e-mail: putu.selly.lindayani@undiksha.ac.id, madeputra@undiksha.ac.id2, \\ idabagussurya.manuaba@undiksha.ac.id
}

\begin{abstract}
Abstrak
Penelitian ini bertujuan untuk mengetahui pengaruh model pembelajaran value clarification technique bermuatan nilai karakter terhadap kompetensi pengetahuan PPKn kelas IV SD gugus III mengwi tahun ajaran 2018/2019. Penelitian ini merupakan penelitian eksperimen semu dengan rancangan Non equivalent posttest only control group design. Populasi pada penelitian ini seluruh kelas IV SD Gugus III Mengwi yang sebanyak 273 siswa. Sampel diambil dengan teknik random sampling, kemudian dilakukan pengundian untuk penentuan kelas eksperimen dan kontrol sehingga kelas IV SD No. 1 Sading sebanyak 34 siswa sebagai kelompok eksperimen dan kelas IV di SD No. 2 Sading sebanyak 33 siswa sebagai kelompok kontrol. Pengumpulan data dilakukan dengan metode tes, Jenis tes yang digunakan adalah tes objektif pilihan ganda biasa. Data yang diperoleh dianalisis menggunakan analisis uji-t polled varian. Berdasarkan hasil analisis diperoleh thitung $=2,353$. Pada taraf signifikansi $5 \%$ dan $\mathrm{dk}=65$, diperoleh $\mathrm{ttabel}=2,000$ maka $\mathrm{HO}$ ditolak. Rerata kompetensi pengetahuan PPKn kelas eksperimen $=80,21$ dan rerata kompetensi pengetahuan PPKn kelas kontrol $=75,48$. Hal ini menunjukkan terdapat perbedaan yang signifikan kompetensi pengetahuan PPKn antara kelompok yang dibelajarkan menggunakan model pembelajaran value clarification technique bermuatan nilai karakter dengan kelompok yang dibelajarkan secara konvensional. Berdasarkan hasil penelitian tersebut dapat disimpulkan bahwa model pembelajaran Value Clarification Technique bermuatan nilai karakter berpengaruh terhadap kompetensi pengetahuan PPKn kelas IV SD gugus III mengwi tahun ajaran 2018/2019.
\end{abstract}

Kata kunci: value clarification technique, nilai karakter, kompetensi pengetahuan PPKn.

\begin{abstract}
This study aims to determine the effect of the value clarification technique learning model with character values on the PPKn knowledge competencies at the fourth grade of cluster three in Mengwi elementary school in 2018/2019. This research is a quasi-experimental study with non-equivalent posttest-only control group design. The total number of the students was 273 students and they were regarded as the population of this study. The samples were taken by random sampling technique, then the raffling was done to determine the experimental class and control class which was resulting in a total of 34 students of fourth-grade students at the SD No. 1 Sading as the experimental group and 33 students of fourth-grade students at SD No. 2 Sading as a control group. The data was collected by applying the test method. The type of test used in this study is the usual multiple choice objective test. The data obtained were analyzed using polled t-test variant analysis. Based on the results of the analysis obtained the $t$-count $=$ 2.353. At the significance level of $5 \%$ and $d k=65$, obtained $t$-table $=2,000$ then $\mathrm{HO}$ is rejected. The average of PPKn knowledge competency of experimental class $=80.21$ and the average PPKn knowledge competency of the control class $=75.48$. This showed that there was a significant difference in PPKn knowledge competencies between the groups being taught using the learning value clarification technique model with the character values and conventionally taught groups. Based on the results of the study it can be concluded that the Value Clarification Technique learning model with character values influences the PPKn knowledge competency of cluster three in Mengwi elementary school in 2018/2019.
\end{abstract}

Keywords : value clarification technique, character values, PPKn knowledge competency. 


\section{Pendahuluan}

Bangsa Indonesia saat ini termasuk sebagai bangsa berkembang, oleh karena itu Indonesia selalu melakukan perbaikan di segala bidang, salah satunya adalah perbaikan di bidang pendidikan. Pendidikan merupakan faktor penting untuk memajukan suatu bangsa. Melalui pendidikan yang baik, diperoleh hal-hal baru sehingga dapat digunakan untuk menciptakan sumber daya manusia yang berkualitas, dan mampu untuk membangun bangsa yang lebih maju. Sehingga setiap bangsa hendaknya memiliki pendidikan yang baik dan berkualitas.

Pendidikan adalah suatu proses pelatihan dan pengajaran terutama diperuntukan kepada anak-anak dan remaja, baik di sekolah-sekolah maupun di kampus-kampus, dengan tujuan memberikan pengetahuan dan mengembangkan keterampilan-keterampilan. Salah satu usaha pemerintah dalam meningkatkan mutu pendidikan adalah dengan adanya perubahan kurikulum sebagai pedoman dalam proses pembelajaran.

Dalam Undang-Undang Nomor 20 Tahun 2003 tentang Sistem Pendidikan Nasional disebutkan bahwa kurikulum adalah seperangkat rencana dan pengaturan mengenai tujuan isi dan bahan pelajaran serta cara yang digunakan sebagai pedoman penyelenggaraan proses pembelajaran untuk mencapai tujuan pendidikan tertentu. Kurikulum yang diterapkan pada jenjang sekolah dasar adalah kurikulum 2013. Pembelajaran pada kurikulum 2013 menggunakan pendekatan saintifik. Menurut Permendikbud, Nomor 103 tahun 2014. Pendekatan saintifik merupakan salah satu cara untuk memberikan pemahaman kepada siswa dalam mengenal, memahami berbagai materi, dan mendorong siswa mencari suatu informasi dari berbagai sumber melalui proses mengamati, menanya, mengumpulkan informasi, menalar/mangasosiasi, dan mengkomunikasi. Dalam kurikulum 2013 siswa diharapkan memiliki daya pikir kreatif, aktif dan inovatif. Oleh karena itu pembelajaran di sekolah dasar diharapkan lebih mendorong siswa untuk termotivasi dalam proses pembelajaran salah satunya menggunakan model pembelajaran. Saat ini, model pembelajaran banyak dikembangkan. Setiap model pembelajaran akan membantu merancang suatu pembelajaran, sehingga setiap siswa bisa mencapai tujuan pembelajaran. Masing-masing model pembelajaran tersebut, telah memuat sintak yang harus diperankan oleh guru dan siswa. Suprijono (2013:45) menyatakan "Model pembelajaran merupakan landasan praktik pembelajaran hasil penurunan teori psikologi pendidikan dan teori belajar yang dirancang berdasarkan analisis terhadap implementasi kurikulum dan implikasinya pada tingkat operasional di kelas. Model pembeljaran dapat diartikan pula sebagai pola yang digunakan untuk penyusunan kurikulum, mengatur materi, dan memberi petunjuk kepada guru di kelas".

Melalui model pembelajaran guru dapat membantu peserta didik mendapatkan informasi, ide, keterampilan, cara berpikir, dan mengekspresikan ide. Model pembelajaran berfungsi pula sebagai pedoman bagi para perancang pembelajaran dan para guru dalam merencanakan aktivitas belajar mengajar. (Suprijono 2013:46)

Salah satu model pembelajaran yang dapat digunakan untuk merancang suatu pembelajaran yaitu model pembelajaran Value Clarification Technique. Model pembelajaran Value Clarification Technique merupakan salah satu model pembelajaran inovatif yang teknik pengajaran untuk membantu siswa dalam mencari dan menentukan suatu nilai yang dianggap baik dalam menghadapi suatu persoalan melalui proses menganalisis nilai yang sudah ada dan tertanam dalam diri siswa. Adisusilo (2012:144) mengatakan bahwa: "Pandangan Hall yang mengatakan VCT merupakan cara atau proses di mana pendidik membantu peserta didik menemukan sendiri nilai-nilai yang melatarbelakangi sikap, tingkah laku, perbuatan serta pilihan-pilihan penting yang dibuatnya". Langkah-langkah Model Pembelajaran Value Clarification Technique di kutip Jarolimek, (dalam Adisusilo 2012:147) mengatakan bahwa ada 7 tahap yang dibagi dalam 3 tingkat yaitu : 
TSCJ, Vol 2 No 2, Tahun 2019

p-ISSN : 2615-4692 e-ISSN : 2615-6105

Tabel 1. Langkah-langkah Model Pembelajaran VCT

\begin{tabular}{|c|c|}
\hline Langkah - langkah & Kegiatan Guru \\
\hline Tingkat 1 & Pada tingkat ini terdapat 3 tahap pembelajaran \\
\hline Kebebasan Memilih & $\begin{array}{l}\text { a. Memilih secara bebas, artinya kesempatan untuk menentukan } \\
\text { pilihan yang menurutnya baik. Nilai yang dipaksakan tidak akan } \\
\text { menjadi miliknya secara penuh. } \\
\text { b. Memilih dari beberapa alternatif, artinya menentukan pilihannya dari } \\
\text { beberapa alternatif pilihan secara bebas. } \\
\text { c. Memilih setelah melakukan analisis pertimbangan konsekuensi } \\
\text { yang akan timbul sebagai akibat atas pilihannya itu. }\end{array}$ \\
\hline Tingl & Pada tingkat ini terdiri atas 2 tahap pembelajaran : \\
\hline Meng & $\begin{array}{l}\text { a. Adanya perasaan senang dan bangga dengan nilai yang menjadi } \\
\text { pilihannya, sehingga nilai tersebut akan menjadi integral pada } \\
\text { dirinya. } \\
\text { b. Menegaskan nilai yang sudah menjadi bagian integral dalam dirinya } \\
\text { di depan umum, yaitu menganggap bahwa nilai itu sebagai } \\
\text { pilihannya sehingga harus berani dengan penuh kesadaran untuk } \\
\text { menunjukkannya di depan orang lain. }\end{array}$ \\
\hline Tingkat 3 Berbuat & $\begin{array}{l}\text { Pada tingkat ini terdiri atas } 2 \text { tahap pembelajaran : } \\
\text { a. Adanya kemauan dan kemampuan untuk mencoba } \\
\text { melaksanakannya. } \\
\text { b. Mau mengulangi perilaku sesuai dengan nilai pilihannya, yaitu nilai } \\
\text { yang menjadi itu harus tercermin dalam kehidupan sehari-hari. }\end{array}$ \\
\hline
\end{tabular}

Mata pelajaran yang lebih menitik beratkan pada ranah kognitif seperti Pendidikan Kewarganegaraan sangat tepat menggunakan model VCT. Seperti tujuan PPKn yang menekankan pada pengalaman dan pembiasaan pada kehidupan sehari-hari yang mengajarkan hak dan kewajiban sebagai warga Negara Indonesia secara santun, jujur, demokratis dan bertanggung jawab. Karakteristik teknik klasifikasi nilai (VCT) sebagai suatu model dalam strategi pembelajaran pengetahuan adalah proses penanaman nilai dilakukan melalui proses analisis nilai yang sudah ada sebelumnya dalam diri siswa kemudian menyelaraskan dengan nilai-nilai baru yang hendak ditanamankan (Taniredja, Faridli, dkk. 2011: 87).

Adapun tujuan model pembelajaran VCT menurut Taniredja, Faridli, dkk. (2011: 88) sebagai berikut (1) mengetahui dan mengukur tingkat kesadaran siswa tentang suatu nilai, sehingga dapat dijadikan sebagai dasar pijak menentukan target nilai yang akan dicapai, (2) menanamkan kesadaran siswa tentang nilai-nilai yang dimiliki baik tingkat maupun sifat yang positif maupun yang negatif untuk selanjutnya ditanamkan kearah peningkatan dan pencapaian target nilai. (3) menanamkan nilai-nilai tertentu kepada siswa melalui cara yang rasional (logis) dan diterima siswa, sehingga pada akhirnya nilai tersebut akan menjadi milik siswa sebagai proses kesadaran moral bukan kewajiban moral. (4) melatih siswa dalam menerima-menilai nilai dirinya dan posisi nilai orang lain, menerima serta mengambil keputusan terhadap sesuatu persoalan yang berhubungan dengan pergaulannya dan kehidupan sehari-hari.

Adapun prinsip-prinsp model pembelajarn VCT menurut Taniredja, Faridli, dkk. (2011: 89) sebagai berikut. (1) penanaman nilai dan pengubahan sikap dipengaruhi banyak factor antara lain faktor potensi diri, kepekaan emosi, intelektual dan faktor lingkungan, norma nilai masyarakat, sistem pendidikan dan lingkungan keluarga dan lingkungan bermain. (2) sikap dan perubahan sikap dipengaruhi oleh stimulus yang di terima siswa dan kekuatan nilai yang telah tertanam atau dimiliki pada diri siswa. (3) nilai,moral dan norma di pengaruhi oleh faktor perkembangnan sehingga guru harus mempertimbangkan tingkat perkembangnan moral (moral development) dari setiap siswa. Tingkat perkembangn moral untuk siswa di pengaruhi oleh usia dan pengaruh lingkungnan terutama lingkungan sosial. (4) pengubahan sikap dan nilai memerlukan keterampilan mengklarifikasi nilai/sikap secara rasional ,sehingga dalam diri siswa muncul kesadaran diri bukan karena rasa kewajiban bersikap tertentu atau berbuat tertentu. (5) pengubahan nilai memerlukan keterbukaan, karena itu pembelajaran pendidikan kewarganegaraan melalui VCT menuntut keterbukaan antara guru dengan siswa.

Kelebihan model pembelajaran VCT Djahiri (dalam Taniredja, Faridli, dkk. 2011: 91) VCT memiliki keunggulan untuk pembelajaran efektif karena : (1) mampu membina dan menanamkan nilai dan moral pada ranah internal side. (2) mampu mengklarifikasi atau 
menggali dan menungkapkan isi pesan materi yang disampaikan selanjutnya akan memudahkan bagi guru untuk menyampaikan makna atau pesan nilai atau moral. (3) mampu mengklarifikasi dan menilai kualitas nilai moral diri siswa, melihat nilai yang ada pada orang lain dan memahami nilai moral yang ada di kehidupan nyata. (4) mampu mengundang, melibatkan, membina dan mengembangkan potensi sikap. (5) mampu memberikan sejumlah pengalaman belajar dari berbagai kehidupan. (6) mampu menangkal, meniadakan, menintervensi dan memadukan berbagai nilai moral dalam sistem nilai dan moral yang adaa dalam diri siswa. (8) memberi gambaran nilai moral yang patut diterima dan menuntun serta memotiasi untuk hidup layak dan bermoral tinggi.

Model pembelajaran VCT akan membantu siswa dalam mencari dan menentukan suatu nilai yang dianggap baik dalam mengahadapi suatu persoalan melalui proses menganalisis nilai yang sudah ada dan tertanam pada diri siswa. Keunggulan dari model VCT ini mampu mengungkapkan isi pesan materi yang disampaikan melalui pemahaman nilai moral dalam kehidupan nyata. Sehingga kegiatan pembelajaran lebih mudah dipahami karena menghubungkan antara konsep dan informasi baru dengan pengetahuan mengenal nilai moral yang telah dimiliki peserta didik sebelumnya, karena model pembelajaran memiliki ragam yang banyak maka guru harus mampu secara selektif memilih model yang tepat sesuai dengan pembelajaran dan pembentukan karakter peserta didik (Nandari, 2013).

Karakter adalah kualitas yang menjadikan ciri bagi seseorang maupun kelompok. Membangun karakter anak dengan menumbuh kembangkan nilai-nilai karakter kepada sesama merupakan cara dapat diterapkan untuk mengembangkan kemampuan dan pembentukan watak peserta didik yang sesuai dengan nilai karakter bangsa (Nandari, 2013). Nilai karakter ini nantinya diharapkan dapat membentuk karakter peserta didik dalam kehidupan sehari-hari. Di sekolah dasar umumnya peserta didik mendapatkan nilai karakter yang diintegrasikan kedalam muatan PPKn.

PPKn merupakan suatu mata pelajaran yang bertujuan untuk membentuk manusia Indonesia seutuhnya berlandasan pada Pancasila, UU, \& Norma yang berlaku di masyarakat. PPKn merupakan salah satu muatan materi yang terdapat pada kurikulum 2013 pada jenjang sekolah dasar. Susanto (2013:226) menyatakan,PPKn adalah pendidikan yang memberikan pemahaman dasar tentang pemerintahan,tata cara demokrasi, tentang kepedulian, sikap, pengetahuan politik yang mampu mengambil keputusan politik secara rasional, sehingga dapat mempersiapkan warga negara yang demokratis dan partisipasif melalui suatu pendidikan yang berorientasi pada pengembangan berpikir kritis dan bertindak demokratis.

"Tujuan PPKn adalah untuk menumbuhkan wawasan dan kesadaran bernegara, serta membentuk sikap dan prilaku cinta tanah air, yang bersendikan kebudayaan bangsa"(Kaelan,2002:3). PPKn di sekolah dasar memberikan pelajaran pada siswa untuk memahami dan membiasakan dirinya dalam kehidupan di sekolah atau diluar sekolah, karena materi PPKn menekankan pada pengalaman dan pembiasaan dalam kehidupan sehari-hari yang di tunjang oleh pengetahuan dan pengertian sederhana sebagai bekal untuk mengikuti pendidikan berikutnya. Melalui materi PPKn juga dapat mendidik siswa agar berpikir kritis, rasional, dan kreatif dalam menanggapi isu kewarganegaraan, dapat berpartisipasi secara aktif dan bertanggung jawab, bertindak secara cerdas dalam kegiatan bermasyarakat, berbangsa, bernegara, serta anti korupsi, siswa dapat berkembang secara positif dan demokratis untuk membentuk diri berdasarkan karakter-karakter masyarakat Indonesia.

Sesuai dengan penjelasan tersebut dapat dirangkum bahwa kompetensi pengetahuan PPKn merupakan seperangkat pengetahuan, keterampilan, dan nilai dasar siswa dalam pemahaman pengetahuan faktual materi PPKn yang meliputi mengingat, memahami, menerapkan, menganalisis, mengevaluasi dan menciptakan untuk mengembangkan dan melestarikan budaya bangsa Indonesia seperti nilai, sikap, dan kepribadian sesuai Pancasila, UUD 1945, serta cinta tanah air.

Pada kenyataannya, masih banyak siswa yang belum menguasai muatan materi PPKn karena dianggap sebagai muatan materi yang sulit. Hal ini terbukti observasi yang dilakukan pada tanggal 08 Januari 2019 dengan guru kelas IV dimasing-masing SD gugus III mengwi tahun ajaran 2018/2019. Berkaitan dengan hal tersebut, setelah dilakukannya observasi diketahui faktor-faktor yang menyebabkan rendahnya hasil kompetensi pengetahuan PPKn siswa seperti : a) siswa kurang aktif dalam proses pembelajaran, b) kurangnya minat belajar siswa, hal ini terlihat dari siswa lebih senang mengobrol saat jam pembelajaran berlangsung, $\mathrm{c}$ ) guru belum pernah menerapkan model pembelajaran. Dengan demikian, dipandang perlu adanya peningkatan kompetensi pengetahuan PPKn siswa. 
Hal ini terbukti dari tingkat pencapain kompetensi pengetahuan PPKn siswa yang masih rendah terbukti dari nilai UAS siswa yang masih jauh dari standar nilai KKM yakni 70 . Hal ini terbukti dari hasil pencapaian kompetensi pengetahuan PPKn di peroleh dari nilai ulangan akhir semester 1 yaitu 273 siswa kelas IV SD gugus III mengwi, 10 siswa mendapatkan nilai (A), 8 siswa mendapatkan nilai ( $A-), 28$ siswa mendapatkan nilai $(B+), 23$ siswa mendapatkan nilai (B), 32 siswa mendapatkan nilai (B-), 30 siswa mendapatkan nilai $\left(\mathrm{C}_{+}\right), 35$ siswa mendapatkan nilai (C), 39 siswa mendapatkan nilai (C-), 38 siswa mendapatkan nilai (D+), dan 30 siswa mendapatkan nilai (D). Dari 273 jumlah siswa kelas IV sebanyak 101 siswa atau $37 \%$ sudah mencapai KKM, sedangkan 172 siswa atau 63\% belum mencapai KKM.

Dari permasalahan tersebut perlu adanya inovasi dalam proses pembelajaran yaitu pembelajaran yang mengutamakan penguasaan kompetensi pengetahuan, berpusat pada siswa, menarik dan menyenangkan serta memberikan pengalaman belajar yang relevan dengan kehidupan nyata. Salah satu cara yaitu menerapkan model pembelajaran yang mampu memfasilitsi siswa untuk memilih dan menentukan nilai yang dianggap benar dan sesuai dengan kehidupannya. Salah satu model yang dapat diterapkan dalam proses pembelajaran untuk membantu siswa dalam menentukan pilihan nilai adalah model pembelajaran Value Clarification Technique (VCT).

Berdasarkan latar belakang masalah yang telah diuraikan, maka dilaksanakan penelitian yang berjudul "Pengaruh Model Pembelajaran Value Clarification Technique Bermuatan Nilai Karakter Terhadap Kompetensi Pengetahuan PPKn Kelas IV SD Gugus III Mengwi Tahun Ajaran 2018/2019"

\section{Metode}

Penelitian ini dilaksanakan di SD Gugus III Mengwi yang terdiri dari 7 SD Negeri yaitu SD No. 1 Sempidi, SD No. 2 Sempidi, SD No. 3 Sempidi, SD No. 1 Sading, SD No. 2 Sading, SD No. 3 Sading dan SD No. 4 Sading. Lokasi ini dipilih karena memiliki aspek pendukung agar penelitian dapat berjalan dengan baik. Adapun aspek pendukung tersebut antara lain seluruh SD di Gugus Gugus III Mengwi secara serentak sudah menerapkan kurikulum 2013, lokasi sekolah dalam satu gugus yang cukup berdekatan sehingga lebih memudahkan dalam melaksanakan penelitian, dan juga tidak terdapatnya kelas unggulan di setiap sekolah dalam gugus tersebut. Kelas yang terpilih sebagai kelompok eksperimen dan kelompok kontrol secara berturut-turut adalah kelas IV SD No. 1 Sading dan kelas IV SD No. 2 Sading.

Adapun waktu penelitian ini dilaksanakan pada bulan November 2018 sampai dengan bulan Mei 2019. Kegiatan yang dilakukan selama penelitian dimulai dari pengajuan judul proposal, revisi judul, penyusunan proposal, bimbingan proposal, seminar proposal, revisi proposal, persiapan penelitian, pengumpulan data, analisis data, penyusunan skripsi dan ujian skripsi. Pelaksanaan penelitian pada masing-masing sampel penelitian dilaksanakan pada bulan April sampai dengan bulan Mei 2019.

Penelitian ini dilakukan dengan menempuh langkah-langkah yang terdiri dari tiga tahapan yaitu: tahap persiapan, tahap pelaksanaan, dan tahap akhir eksperimen. Adapun uraian dari setiap tahapan yaitu pada tahap persiapan, hal yang dilakukan adalah melakukan wawancara dengan kepala gugus, menyusun RPP beserta LKS, mengkonsultasikan instrumen penelitian bersama wali kelas dan dosen pembimbing, mengadakan uji coba instrumen, melakukan pengundian untuk menentukan kelompok eksperimen dan kelompok kontrol, meminta nilai pre test, serta menguji kesetaraan data pre test dengan uji t.

Kemudian pada tahap pelaksanaan hal yang dilakukan adalah memberikan perlakuan pada kelas eksperimen berupa model pembelajaran value clarification technique bermuatan nilai karakter sebanyak delapan kali pertemuan dengan rincian, satu kali pemberian uji coba instrumen, enam kali penyampaian materi, dan satu kali pemberian post test, serta memberikan perlakuan pada kelas kontrol berupa pembelajaran konvensional sebanyak delapan kali dengan rincian: satu kali meminta nilai pre test, enam kali penyampaian materi, dan satu kali pemberian post test. Pada tahap akhir eksperimen hal yang dilakukan adalah menganalisis data hasil penelitian dan melakukan uji hipotesis.

Tujuan penelitian ini adalah untuk mengetahui pengaruh yang signifikan kompetensi pengetahuan PPKn siswa yang dibelajarkan menggunakan model pembelajaran value clarification technique bermuatan nilai karakter dan yang tidak dibelajarkan menggunakan value clarification technique bermuatan nilai karakter pada kelas IV SD Gugus III Mengwi Tahun Ajaran 2018/2019. Jenis penelitian ini adalah penelitian eksperimen semu. Sebab, kemampuan dalam mengamati perilaku siswa sebaai objek penelitian sangat terbatas, utamanya ketika 
siswa berada di luar kelas. Selain itu, peneliti juga tidak memiliki kemampuan untuk mengubah kelas dan kondisi yang sudah ada sebelumnya. Jenis penelitian eksperimen semu dengan rancangan only posttest control group design (Agung, 2014:163). Desain tersebut dapat diformulasikan dengan gambar sebagai berikut.

\begin{tabular}{|c|c|c|}
\hline Kelas & Perlakuan & Post-test \\
\hline Eksperimen & $\mathrm{X}_{1}$ & $\mathrm{O}_{1}$ \\
\hline Kontrol & $\mathrm{X}_{2}$ & $\mathrm{O}_{2}$ \\
\hline
\end{tabular}

Gambar. 1. Desain Eksperimen "Non equivalent post test only control group design" (Sumber: Agung,2014:163)

Keterangan:

$\mathrm{X}_{1}=$ Perlakuan dengan penerapan model pembelajaran (Value Clarification Technique) bermuatan nilai karakter pada kelompok eksperimen.

$\mathrm{X}_{2} \quad$ = Dibelajarkan secara konvensional pada kelompok kontrol.

$\mathrm{O}_{1} \quad$ = Menyatakan pengamatan akhir (post-test) pada kelompok eksperimen

$\mathrm{O}_{2}=$ Menyatakan pengamatan akhir (post-test) pada kelompok kontrol

Sebelum penelitian ini dilakukan, kedua kelompok yang telah terpilih dilakukan penyetaraan terlebih dahulu. Berdasarkan hal tersebut, maka dalam penelitian ini nilai pre test digunakan untuk menyetarakan kelompok.

Dalam melakukan sebuah penelitian harus ditentukan populasi yang dipergunakan. Menurut Sugiyono (2011:80) "populasi adalah wilayah generalisasi yang terdiri dari obyek atau subyek yang menjadi kuantitas dan karakteristik tertentu yang ditetapkan oleh peneliti untuk dicari dan kemudian ditarik kesimpulannya". Sedangkan menurut Dantes (2012:37) "populasi adalah sejumlah kasus yang memenuhi seperangkat kreteria tertentu, yang ditentukan peneliti". Berdasarkan pendapat kedua ahli tersebut dapat dirangkum bahwa populasi pada prinsipnya adalah semua anggota atau keseluruhan dari objek individu yang memiliki karakteristik tertentu yang ingin diteliti oleh peniliti lalu dipelajari dan ditarik kesimpulannya. Populasi dalam penelitian ini adalah kelas IV SD Gugus III Mengwi tahun ajaran 2018/2019 yang terdiri dari 8 kelas dalam 7 sekolah. Jumlah populasi dalam penelitian ini adalah 273 siswa. Populasi dalam penelitian ini bersifat setara sesuai dengan informasi awal yang diperoleh pada saat penjajagan awal ke sekolah.

Setelah mengetahui populasi, langkah selanjutnya adalah menentukan sampel penelitian. Sugiyono (2011:81) "Sampel adalah bagian dari jumlah dan karakteristik yang dimiliki oleh populasi tersebut". Apa yang dipelajari dari sampel itu, kesimpulannya akan dapat diberlakukan untuk populasi. Untuk itu sampel yang diambil dari populasi harus representatif (mewakili).Teknik yang digunakan dalam pengambilan sampel pada penelitian ini adalah random sampling dengan mengacak kelas, sehingga setiap kelas memiliki peluang yang sama untuk menjadi sampel penelitian. Sampel dalam penelitian ini adalah kelas IV SD No 1 Sading sebanyak 34 siswa sebagai kelompok eksperimen dan kelas IV SD No. 2 Sading sebanyak 33 siswa sebagai kelompok kontrol.

Penelitian ini memiliki 2 variabel, yaitu variabel terikat dan variabel bebas. variabel terikat adalah variabel yang dipengaruhi variabel bebas. Variabel terikat dalam penelitian ini adalah kompetensi pengetahuan PPKn siswa sedangkan variabel bebas adalah variabel yang menyebabkan atau mempengaruhi perubahan atau timbulnya variabel terikat yang akan diamati, variabel bebas dalam penelitian ini adalah model pembelajaran value clarification technique bermuatan nilai karakter.

Dalam penelitian ini data yang dikumpulkan diperoleh dari data hasil pre test dan post test yang dianalisis menggunakan uji-t untuk memperoleh data kompetensi pengetahuan PPKn. 
Setelah nilai pre test diperoleh, siswa kemudian belajar menggunakan model pembelajaran value clarification technique bermuatan nilai karakter pada kelompok eksperimen dan dibelajarkan tidak menggunakan value clarification technique bermuatan nilai karakter pada kelompok kontrol.

Untuk mendapatkan data tersebut digunakan tes kompetensi pengetahuan PPKn. Menurut Jakni (2016:99) "Tes merupakan sekumpulan pertanyaan yang digunakan untuk mengumpulkan data mengenai kemampuan kognitif siswa sebelum atau setelah proses pembelajaran berlangsung". Sedangkan menurut Arikunto (2015:67) "Tes merupakan alat atau prosedur yang digunakan untuk mengetahui atau mengukur sesuatu dalam suasana, dengan cara atau aturan-aturan yang sudah ditentukan". Jadi dapat dirangkum tes adalah pengumpulan data serangkaian pertanyaan atau latihan yang digunakan untuk mengukur pengetahuan. Dalam penelitian ini, data yang dikumpulkan adalah berupa hasil kompetensi pengetahuan PPKn kelas IV SD gugus III mengwi. Jenis tes yang akan digunakan dalam penelitian ini untuk mengukur hasil belajar siswa adalah tes objektif dalam bentuk pilihan ganda biasa dengan 4 pilihan jawaban (A, B, C atau D). Setiap item diberikan skor 1 apabila siswa menjawab benar disesuaikan dengan kunci jawaban dan skor 0 apabila siswa menjawab salah. Sebelum tes diberikan pada masing-masing kelompok, terlebih dahulu dilakukan validasi secara teoretis dengan menggunakan kisi-kisi dan di konsultasikan pada ahli, selanjutnya dilakukan validasi empirik dengan jumlah responden 42 siswa. Dari hasil uji instrumen yang meliputi uji validitas, uji daya beda, tingkat kesukaran, dan uji reliabilitas diperoleh 34 butir test yang dinyatakan valid atau layak digunakan dalam penelitian dari total 45 butir tes yang di uji cobakan.

Metode dan teknik analisis data yang dilakukan adalah menghitung analisis statistik inferensial. Statistik inferensial adalah untuk menguji hipotesis dan menarik kesimpulan berdasarkan hasil pengujian terhadap hipotesis. Teknik yang digunakan untuk menganalisis kompetensi pengetahuan PPKn dalam penelitian ini adalah uji-t. Sebelum uji hipotesis statistik dengan uji $t$ dilakukan, terlebih dahulu dilakukan uji normalitas sebaran data dan uji homogenitas varians. Jika data yang diperoleh sudah memenuhi prasyarat uji normalitas dan homogenitas maka analisis yang digunakan adalah statistik parametrik. "Jika $n 1 \neq n 2$, varians homogen dapat digunakan t-test dengan polled varians, dengan derajat kebebasan (n1+n2)-2" (Koyan, 2012:37). Dengan demikian, analisis statistik yang digunakan untuk menguji hipotesis dalam penelitian ini adalah uji beda mean (uji t) dengan rumus polled varians, dengan kriteria pada taraf signifikansi $5 \%(\alpha=0,05)$ dan $d k=n_{1}+n_{2}-2$. Jika harga $t_{\text {hitung }} \leq t_{\text {tabel }}$, maka $H_{0}$ diterima, dan jika harga $t_{\text {hitung }}>t_{\text {tabel}}$, maka $H_{0}$ ditolak.

\section{Hasil dan Pembahasan}

Penelitian ini merupakan penelitian yang berbentuk quasi experiment atau eksperimen semu yang menggunakan rancangan onlyposttest control group design yang dianalisis menggunakan uji t. Objek dalam penelitian ini adalah kompetensi pengetahuan PPKn kelas IV SD Gugus III Mengwi tahun ajaran 2018/2019 yang dibelajarkan dengan model pembelajaran Value Clarification Technique bermuatan nilai karakter pada kelompok eksperimen dan kelompok yang dibelajarkan dengan pembelajaran konvensional pada kelompok kontrol.

Setelah kelompok eksperimen dan kelompok kontrol diberikan perlakuan, kemudian kedua kelompok tersebut diberikan post test untuk mendapatkan data kompetensi pengetahuan PPKn dari masing-masing kelompok. Setelah data post test dianalisis, diketahui bahwa sebaran data post test kompetensi pengetahuan PPKn berdistribusi normal dan memiliki varians yang homogen. Berdasarkan hasil analisis diperoleh $t_{\text {hitung }}=2,353$ dan kemudian dibandingkan dengan harga $t_{\text {tabel }}=2,000$. Karena $t_{\text {hitung }}>t_{\text {tabel }} 2,353>2,000$ maka hipotesis nol $\left(H_{0}\right)$ ditolak. Berikut disajikan rekapitulasi hasil analisis data dengan menggunakan uji t pada Tabel 1.

Tabel 2. Rekapitulasi Analisis Uji t

\begin{tabular}{clcccccc}
\hline No & \multicolumn{1}{c}{ Sampel } & $\mathbf{N}$ & $\mathbf{D k}$ & $\overline{\boldsymbol{X}}$ & $\mathbf{s}^{\mathbf{2}}$ & $\mathbf{t}_{\text {hitung }}$ & $\mathbf{t}_{\text {tabel }}$ \\
\hline 1 & Kelompok Eksperimen & 34 & \multirow{2}{*}{65} & 80,21 & 86,47 & \multirow{2}{*}{2,353} & 2,000 \\
2 & Kelompok Kontrol & 33 & & 75,48 & 48,70 & \\
\hline
\end{tabular}

Berdasarkan hasil perhitungan uji-t diperoleh $t_{\text {hitung }}=2,353$. Hasil tersebut kemudian dibandingkan dengan harga $t_{\text {tabel }}$ dengan $\mathrm{dk}=34+33-2=65$ dan taraf signifikansi $5 \%$ sehingga diperoleh harga $t_{\text {tabel }}=2,000$, karena $t_{\text {hitung }}>t_{\text {tabel }}$ maka $H_{0}$ ditolak. Ini berarti terdapat 
perbedaan yang signifikan kompetensi pengetahuan PPKn antara kelompok siswa yang dibelajarkan dengan model pembelajaran Value Clarification Technique bermuatan Nilai Karakter dan kelompok yang dibelajarkan dengan pembelajaran konvensional pada kelas IV SD Gugus III Mengwi Tahun Ajaran 2018/2019.

Rata-rata kompetensi pengetahuan PPKn siswa kelas eksperimen lebih dari rata-rata kompetensi pengetahuan PPKn siswa kelas kontrol $(\bar{X}=80,21>\bar{X}=75,48)$. Sehingga dapat disimpulkan bahwa penerapan model pembelajaran Value Clarification Technique bermuatan Nilai Karakter berpengaruh terhadap kompetensi pengetahuan PPKn Kelas IV SD Gugus III Mengwi Tahun Ajaran 2018/2019.

Pada kelas eksperimen, kegiatan pembelajaran materi PPKn menerapkan model pembelajaran value clarification technique bermuatan nilai karakter. Dengan menggunakan model pembelajaran value clarification technique, minat belajar siswa dapat ditingkatkan melalui pembelajaran PPKn yang lebih bermakna. Pelajaran PPKn menjadi bermakna bagi siswa, karena model ini mampu memberikan siswa suatu permasalahan yang harus diselesaikan sendiri oleh masing-masing siswa, dimana tahap yang dilalui dalam memecahkan masalah yaitu mulai dari siswa memahami permasalahan sampai siswa menemukan teknik atau cara yang digunakan dalam memecahkan masalah tersebut. Sehingga materi yang dipelajari jauh lebih melekat pada diri siswa. Proses pembelajaran konvensional yang berlangsung kurang mampu mengembangkan kemampuan berpikir peserta didik. Kondisi seperti ini, juga akan berdampak pada, gairah siswa untuk mengikuti pembelajaran secara pasif, sehingga akan berdampak pada kompetensi pengetahuan PPKn siswa yang kurang optimal. Untuk itu perlu adanya inovasi pembelajaran yang dapat mengoptimalkan kompetensi pengetahuan PPKn siswa. Dengan menerapkan model pembelajaran Value Clarification Technique bermuatan nilai karakter.

Model pembelajaran value clarification technique merupakan salah satu model pembelajaran inovatif yang teknik pengajarannya membantu siswa dalam mencari dan menentukan suatu nilai yang dianggap baik dalam menghadapi persoalan melalui proses menganalisis nilai yang sudah ada dan tertanam dalam diri siswa. Selain itu, minat belajar siswa dapat ditingkatkan dengan menanamkan 5 nilai karakter, yaitu disiplin, mandiri, kreatif, rasa ingin tahu dan gemar membaca.

Hal tersebut didukung oleh pendapat Djahiri (dalam Taniredja, Faridli, dkk. 2011) yang menyatakan bahwa "kelebihan model pembelajaran value clarification technique yaitu, mampu mengklarifikasi atau menggali dan menungkapkan isi pesan materi yang disampaikan selanjutnya akan memudahkan bagi guru untuk menyampaikan makna atau pesan nilai atau moral".

Hasil penelitian ini mendukung penelitian-penelitian yang telah ada sebelumnya, seperti (a) Penelitian yang dilakukan Nandari (2013) yang menyimpulkan bahwa model pembelajaran value clarification technique bermuatan cerita dilema moral berpengaruh terhadap hasil belajar PPKn siswa kelas IV SD Negeri 1 Kamasan Tahun Pelajaran 2012/2013 dengan hasil analisis menunjukan bahwa terdapat perbedaan hasil belajar Pendidikan Kewarganegaraan yang signifikan antara siswa yang mengikuti pembelajaran value clarification technique bermuatan cerita dilema moral dengan model pembelajaran dan siswa yang mengikuti pembelajaran dengan model pembelajaran konvensional. (b) Penelitian yang value clarification technique dilakukan Permatasari (2017) yang menyimpulkan bahwa model pembelajaran terhadap sikap demokratis siswa pada mata pelajaran PPKn kelas III SD Negeri Gedongkiwo dengan hasil analisis menunjukan bahwa terdapat pengaruh signifikan penggunaan model value clarification technique terhadap sikap demokratis siswa pada mata pelajaran PPKn .

Berdasarkan paparan tersebut, dapat dirangkum bahwa pembelajaran menggunakan model pembelajaran Value Clarification Technique bermuatan nilai karakter berpengaruh terhadap kompetensi pengetahuan PPKn kelas IV SD Gugus III Mengwi tahun ajaran 2018/2019

\section{Simpulan dan Saran}

Berdasarkan hasil analisis data kompetensi pengetahuan PPKn kelompok yang belajar menggunakan model pembelajaran value clarification technique bermuatan nilai karakter pada siswa kelas IV SD Gugus III Mengwi Tahun Ajaran 2018/2019, diperoleh rerata kompetensi pengetahuan PPKn kelas IV SD NO. 1 Sading tahun ajaran 2018/2019 setelah dibelajarkan menggunakan model pembelajaran value clarification technique bermuatan nilai karakter sebesar 80,21 . Sedangkan berdasarkan hasil analisis data kompetensi pengetahuan PPKn 
kelompok yang dibelajarkan menggunakan pembelajaran konvensional pada siswa kelas IV SD Gugus III Mengwi Tahun Ajaran 2018/2019, diperoleh nilai rerata kompetensi pengetahuan PPKn kelas IV SD NO. 2 Sading tahun ajaran 2018/2019 sebesar 75,48. Dengan demikian, dapat dinyatakan bahwa terdapat perbedaan yang signifikan kompetensi pengetahuan PPKn siswa yang belajar menggunakan model pembelajaran value clarification technique bermuatan nilai karakter dan yang belajar menggunakan pembelajaran konvensional pada kelas IV SD III Mengwi Tahun Ajaran 2018/2019. Hal ini terbukti dari hasil analisis uji t kompetensi pengetahuan PPKn kelas yang belajar menggunakan model pembelajaran value clarification technique bermuatan nilai karakter dan kelompok siswa yang belajar menggunakan pembelajaran konvensional pada kelas IV SD Gugus III Mengwi Selatan Tahun Ajaran $2018 / 2019$ diperoleh thitung $=2,353$ dan pada taraf signifikansi $5 \%$ dengan $\mathrm{dk}=(34+33-2)=$ 65 diperoleh ttabel $=2,000$. Dengan demikian, nilai thitung 2,353 $>2,000$, sehingga $\mathrm{Ho}$ atau hipotesis nol ditolak. Hal ini berarti terdapat perbedaan yang signifikan kompetensi pengetahuan PPKn antara kelompok siswa yang dibelajarkan menggunakan model pembelajaran value clarification technique bermuatan nilai karakter dan kelompok siswa yang dibelajarkan menggunakan pembelajaran konvensional pada kelas IV SD Gugus III Mengwi tahun ajaran 2018/2019. Dengan demikian, dapat disimpulkan bahwa model pembelajaran value clarification technique bermuatan nilai karakter berpengaruh terhadap kompetensi pengetahuan PPKn kelas IV SD Gugus III Mengwi tahun ajaran 2018/2019.

Adapun saran yang ingin disampaikan melalui penelitian ini yaitu: (1) kepada guru, hendaknya dapat menambah wawasannya mengenai inovasi pembelajaran sehingga mampu menerapkan ataupun mengembangkan pembelajaran di kelas secara lebih inovatif dan bervariasi agar dapat memberikan dampak positif dalam meningkatkan kompetensi pengetahuan siswa. Salah satu model pembelajaran yang dapat diterapkan oleh guru adalah model pembelajaran Value Clarification Technique bermuatan nilai-nilai karakter. (2) kepada kepala sekolah, hendaknya menyediakan sarana yang maksimal untuk menunjang pembelajaran agar siswa semakin termotivasi untuk belajar dan memanfaatkan sarana tersebut untuk mengoptimalkan kompetensi siswa sehingga mutu sekolah menjadi semakin meningkat. (3) kepada peneliti lainnya diharapkan melakukan penelitian lebih lanjut pada materi pembelajaran yang berbeda atau dapat pula dilakukan penelitian lebih lanjut dengan menggunakan model pembelajaran Value Clarification Technique bermuatan nilai-nilai karakter pada sumber data/sampel yang berbeda khususnya pada muatan materi PPKn sehingga hasil penelitian benar-benar dapat menggambarkan keadaan sesungguhnya yang terjadi di lapangan.

\section{Daftar Pustaka}

Adisusilo, Sutarjo.J.R. 2012.Pembelajaran Nilai Karakter Kontruktivisme dan VCT sebagai Inovasi Pendekatan Pembelajaran Afektif. Bandung: Rajagrafindo Persada.

Agung, A. A. G. 2014. Metodologi Penelitian Pendidikan. Yogyakarta: Aditya Media Publishing.

Dantes, Nyoman. 2012. Metode Penelitian.Yogyakarta: Andi.

Jakni. 2016. Metodelogi Penelitian Eksperimen Bidang Pendidikan. Bandung: Alfabeta

Kaelan, H. M.S. 2002. Pendidikan Kewarganegaraan. Yogyakarta: Paradigma Yogyakarta

Koyan, I Wayan. 2012. Statistika Terapan (Teknik Analisis Data Kuantitatif). Singaraja: UNDIKSHA.

Nandari, Ida Ayu Tri. 2013 "Pengaruh Model Pembelajaran VCT Bermuatan Cerita Berdilema Moral Terhadap Hasil Belajar Pendidikan Kewarganegaraan Siswa Kelas IV SD Negeri 1 Kamasan". Tersedia Pada http://ejournal.undiksha.ac.id/index.php/JJPGSD/article/view/1385 (Diakses Tanggal 15 Desember 2018)

Peraturan Menteri Pendidikan dan Kebudayaan Republik Indonesia Nomor Nomor 103 Tahun 2014 tentang Pembelajaran pada Pendidikan Dasar dan Pendidikan Menengah dengan 
TSCJ, Vol 2 No 2, Tahun 2019

p-ISSN : 2615-4692 e-ISSN : 2615-6105

Rahmat Tuhan Yang Maha Esa Menteri Pendidikan dan Kebudayaan Republik Indonesia. 2014. Jakarta: Kementrian Pendidikan dan Kebudayaan.

Permatasari, Dewi. 2017 "Pengaruh Penggunaan Model Pembelajara Value Clarification Technique Terhadap Sikap Demokratis Siswa Pada Mata Pelajaran PKn Kelas III SD Negeri Gendongkiwo". Tersedia Pada http://eprint.uny.ac.id/52676/ (Diakses Tanggal 15 Desember 2018)

Sugiyono. 2011. Metode Penelitian Kuantitatif Kualitatif dan R\&D. Bandung: Alfabeta.

Suprijono, Agus. 2013.Cooperative Learning. Yogyakarta: Pustaka Belajar

Taniredja, Faridli, dkk. 2012. Model-Model Pembelajaran Inovatif. Bandung: Alfabeta

Undang-Undang Nomor 20 Tahun 2003 tentang Sistem Pendidikan Nasional, 1990. Jakarta: PT Arnas Duta Jaya. 